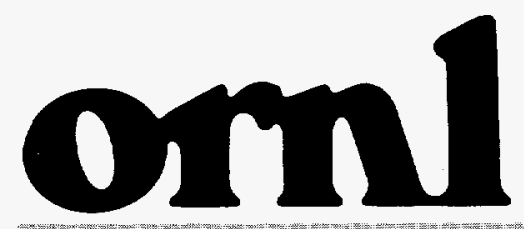

OAK RIDGE NATIONAL LABORATORY
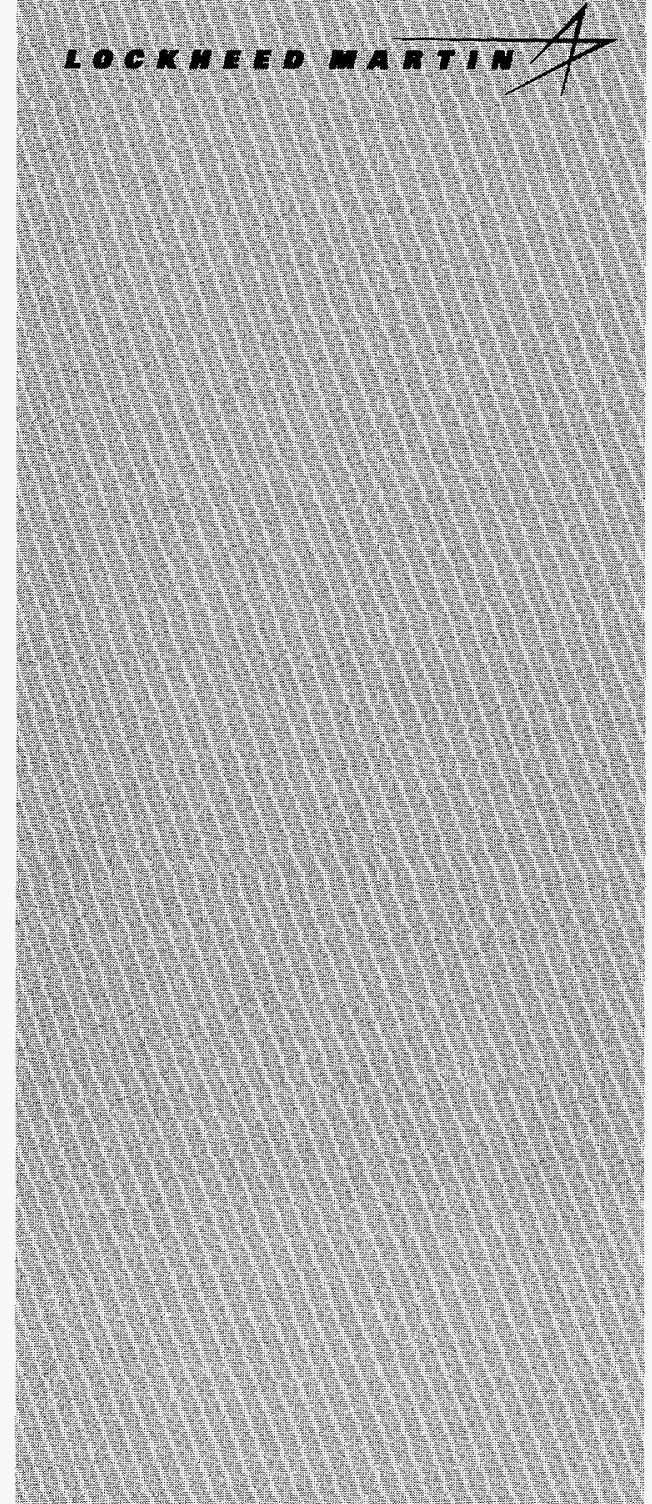

WAWAED AND OPERATED BY LOGKHEED MARTH ENERGY RESEARGH CORPORATION FOA THE UATEO ST ATES DEDRTEMT OF ENEROY

\section{History of the U.S. Weapons-Usable Plutonium Disposition Program Leading to DOE's Record of Decision}

\author{
D. J. Spellman \\ J. F. Thomas \\ R. G. Bugos
}

RECEIVED

MAR 121998

OSTI 
This report has been reproduced directly from the best available copy.

Available to DOE and DOE contractors from the Office of Scientific and Technical Information, P.O. Box 62, Oak Ridge, TN 37831; prices available from (423) 576-8401.

Available to the public from the National Technical Information Service, U.S. Department of Commerce, 5285 Port Royal Rd., Springfield, VA 22161.

This report was prepared as an account of work sponsored by an agency of the United States Government. Neither the United States Government nor any agency thereof, nor any of their employees, makes any warranty, express or implied, or assumes any legal liability or responsibility for the accuracy, completeness, or usefulness of any information, apparatus, product, or process disclosed, or represents that its use would not infringe privately owned rights. Reference herein to any specific commercial product, process, or service by trade name, trademark, manufacturer, or otherwise, does not necessarily constitute or imply its endorsement, recommendation, or favoring by the United States Government or any agency thereof. The views and opinions of authors expressed herein do not necessarily state or reflect those of the United States Government or any agency thereof. 


\section{DISCLAIMER}

Portions of this document may be illegible electronic image products. Images are produced from the best available original document. 
ORNL/TM-13416

Dist. Category UC-523

\title{
HISTORY OF THE U.S. WEAPONS-USABLE PLUTONIUM DISPOSITION PROGRAM LEADING TO DOE'S RECORD OF DECISION
}

\author{
D. J. Spellman \\ J. F. Thomas \\ R. G. Bugos
}

Date Published: April 1997

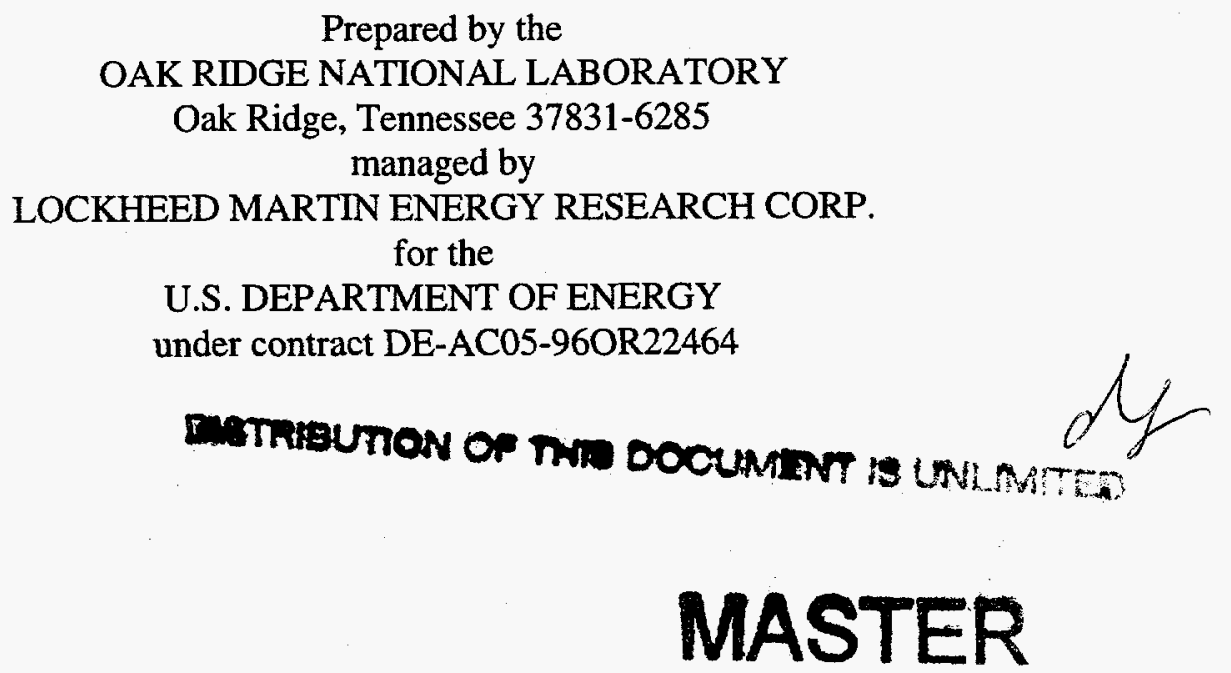


Page Intentionally Blank 
CONTENTS

\section{Page}

ABSTRACT.

1. PURPOSE

2. BACKGROUND CONCERNING SURPLUS WEAPONS-USABLE PLUTONIUM DISPOSITION.

2.1 RECENT DEVELOPMENTS

2.2 DOE'S ROLE IN PLUTONIUM DISPOSITION..

2.2.1 Spent Fuel Standard.

2.2.2 Decision Process Leading to ROD

3. BACKGROUND AND SCOPE OF REACTOR-OPTION STUDIES.

3.1 PLUTONIUM DISPOSITION STUDIES FOR NEW REACTOR DESIGNS

3.2 PLUTONIUM DISPOSITION STUDIES FOR EXISTING REACTORS.

3.3 REACTOR ALTERNATIVE SUMMARY REPORTS

3.3.1 Existing LWR Alternative

3.3.2 CANDU HWR Alternative.

3.3.3 Partially Complete LWR Alternative

3.3.4 Evolutionary LWR Alternative.

3.4 OPTIMIZATION AND IMPLEMENTATION STUDIES FOR EXISTING REACTORS

3.4.1 Westinghouse Electric Corporation...

3.4.2 GE Nuclear Energy.

3.4.3 ABB-CE..

3.4.4 AECL Technologies, Inc., Study of CANDU Reactors 


\title{
HISTORY OF THE U.S. WEAPONS-USABLE PLUTONIUM DISPOSITION PROGRAM BEFORE THE RECORD OF DECISION
}

\author{
D. J. Spellman \\ J. F. Thomas \\ R. G. Bugos
}

\begin{abstract}
This report highlights important events and studies concerning surplus weapons-usable plutonium disposition in the United States. Included are major events that led to the creation of the U.S. Department of Energy (DOE) Office of Fissile Materials Disposition in 1994 and to that DOE office issuing the January 1997 Record of Decision for the Storage and Disposition of Weapons-Usable Fissile Materials Final Programmatic Environmental Impact Statement. Emphasis has been given to reactor-based plutonium disposition alternatives.
\end{abstract}

\section{PURPOSE}

The U.S. Department of Energy's (DOE's) strategy for disposition of surplus plutonium ${ }^{1}$ is to pursue irradiating some of the surplus plutonium as mixed-oxide (MOX) fuel in existing, domestic commercial reactors and immobilizing the remainder of the surplus plutonium in glass or ceramic materials. Both methods include subsequent disposal in a geological repository pursuant to the Nuclear Waste Policy Act. DOE may also choose to irradiate MOX fuel in Canadian deuterium-uranium (CANDU) reactors if an agreement among Russia, Canada, and the United States is reached. The timing and extent to which these disposition approaches (immobilization or MOX fuel) are ultimately deployed will depend on the results of future technology development and demonstrations, follow-on (tiered) site-specific environmental review, contract negotiations, and detailed cost reviews, as well as nonproliferation considerations and agreements with Russia and other nations. 1

This document is one in a series of topical reports written in support of DOE's Program Acquisition Strategy for Obtaining Mixed-Oxide Fuel Fabrication and Reactor Irradiation Services (PAS) [formerly known as Procurement Implementation Plan for Acquisition of Mixed-Oxide Fuel Fabrication Services and Reactor Irradiation Services (PIP)]. ${ }^{2}$ The series of topical reports is intended to increase access to available information for parties interested in responding to PAS and the subsequent request for proposal. These topical reports address subjects relevant to DOE's strategy concerning disposition of surplus plutonium by irradiating MOX fuel in existing, domestic commercial reactors. This report gives general background information concerning the DOE Fissile Materials Disposition Program (FMDP) with emphasis on reactorbased options. Although significant useful background information is given in this report, a large body of useful information is available from other sources, and specific instructions for obtaining pertinent publicly available documents are given in the Appendix.

\section{BACKGROUND CONCERNING SURPLUS WEAPONS-USABLE PLUTONIUM DISPOSITION}

The first and second Strategic Arms Reductions Treaties (START I and START II) call for deep reductions in the strategic nuclear forces of both the United States and the former Soviet Union. In addition, in the aftermath of the Cold War, both the United States and Russia have initiated steps to increase the pace of strategic disarmament, including unilateral pledges made by Presidents Bush, Clinton, Gorbachev, and 
Yeltsin. Under START and subsequent unilateral initiatives, some 10,000 to 20,000 warheads in the United States (and a similar or greater number in the former Soviet Union) have been declared "surplus" to national security needs. Thus, significant quantities of weapons-usable fissile materials have or will become surplus to national defense needs in both the United States and Russia. These stocks of fissile materials pose significant dangers to national and international security. The dangers exist not only in the potential proliferation of nuclear weapons but also in the potential for environmental, safety, and health (ES\&H) consequences if surplus fissile materials are not properly managed.

\subsection{RECENT DEVELOPMENTS}

With the end of the Cold War, the signing of START I and START II, and the pledges made by Presidents Bush, Gorbachev, and Yeltsin, arms reduction efforts proceeded on an unprecedented scale. Accompanying these events were pressing international security problems related to the nuclear material stockpiles from weapons dismantling programs. This situation led to a March 1992 request from B. Scowcroft, then the National Security Advisor to President Bush, requesting a full-scale study of management and disposition options for surplus plutonium by the National Academy of Sciences' (NAS') Committee on International Security and Arms Control (CISAC). ${ }^{3}$ The Clinton administration confirmed CISAC's mandate in January $1993 .^{3}$

In September 1993, President Clinton issued the U.S. Nonproliferation and Export Control Policy, ${ }^{4}$ which commits the United States to undertake a comprehensive management approach to the growing accumulation of fissile materials from dismantled nuclear weapons. This policy directs the United States to do the following:

- Seek to eliminate, where possible, accumulation of stockpiles of highly enriched uranium or plutonium, and to ensure that where these materials already exist they are subject to the highest standards of safety, security, and international accountability.

- Initiate a comprehensive review of long-term options for plutonium disposition, taking into account technical, nonproliferation, environmental, budgetary and economic considerations. Russia and other nations with relevant interests and experience will be invited to participate in the study. ${ }^{4}$

Further, in January 1994, President Clinton and Russia's President Yeltsin issued the Joint Statement Between the United States and Russia on Nonproliferation of Weapons of Mass Destruction and Means of Their Delivery. ${ }^{5}$ In accordance with these policies, the focus of the U.S. nonproliferation efforts is fivefold: to secure nuclear materials in the former Soviet Union; to ensure safe, secure, long-term storage and disposition of surplus fissile materials; to establish transparent and irreversible nuclear reductions; to strengthen the nuclear nonproliferation regime; and to control nuclear exports.

To demonstrate the U.S. commitment to the five objectives articulated in the joint statement, President Clinton announced on March 1, 1995, that 200 metric tons (MT) of U.S. fissile materials ( $38.2 \mathrm{MT}$ of which is weapons-usable plutonium) had been declared surplus to U.S. nuclear defense needs. ${ }^{6.7}$ In addition, it is anticipated that several metric tons of reactor-grade material containing weapons-usable plutonium will be declared surplus in the future. Thus, it appears that $\sim 50 \mathrm{MT}$ of weapons-usable plutonium will become surplus to U.S. defense needs.

To fulfill the March 1992 request to the NAS CISAC for a full-scale study of management and disposition options for surplus plutonium, NAS formed the Panel on Reactor-Related Options for the Disposition of Excess Weapons Plutonium in November 1992. NAS's efforts resulted in two reports, supported in part by the DOE Office of Nuclear Energy. 3,8

In its 1994 report by CISAC, Management and Disposition of Excess Weapons Plutonium, ${ }^{3}$ NAS stated, "The existence of this surplus material constitutes a clear and present danger to national and international security." In many respects, the nuclear threat posed by this material is now more diffuse, harder to manage, and more dangerous than the nuclear tensions of the Cold War era. The international community is concerned about the adequacy of safeguards and security (S\&S) for this material, the dangers associated with the potential proliferation of nuclear weapons, and the potential for ES\&H consequences if 
surplus fissile materials are not properly managed. In a joint communiqué from the Moscow Nuclear Safety Summit, ${ }^{9}$ the leaders of the seven largest industrial countries and the Russian Federation endorsed the need to render surplus plutonium in Russia and the United States as proliferation-resistant as possible.

In both the 1994 study and the 1995 companion report, Management and Disposition of Excess Weapons Plutonium, Reactor-Related Options, ${ }^{8}$ CISAC and the Panel on Reactor-Related Options for the Disposition of Excess Weapons Plutonium concluded that two plutonium disposition alternatives were the most promising. The two alternatives identified are the fabrication and use of MOX fuel, without reprocessing, in nuclear reactors; and vitrification in combination with high-level radioactive waste. Furthermore, it was recommended that these alternatives be pursued jointly by the United States and Russia.

\subsection{DOE'S ROLE IN PLUTONIUM DISPOSITION}

Following President Clinton's September 1993 nonproliferation policy announcement, ${ }^{4}$ an Interagency Working Group (IWG) was established to conduct a comprehensive review of the options for disposition of surplus plutonium from nuclear weapons activities of the United States and the former Soviet Union. The IWG is co-chaired by the White House Office of Science and Technology Policy and the National Security Council. In response to the President's nonproliferation policy, Secretary O'Leary created a department-wide project for control and disposition of surplus fissile materials on January 24 , 1994. Later that year, the Office of Fissile Materials Disposition (DOE/MD) was created to ensure that this project was carried out. DOE, with its national laboratories, has the lead role for evaluating technical options and developing analyses of economic, schedular, environmental, and other aspects of the potential disposition options.

\subsubsection{Spent Fuel Standard}

In June 1994, DOE issued a Notice of Intent to prepare a programmatic environmental impact statement (PEIS) and to issue a Record of Decision (ROD) regarding long-term storage and disposition of weapons-usable fissile materials. The primary goal of disposition is to render weapons-usable fissile materials inaccessible and unattractive for weapons use while protecting human health and the environment. In its 1994 report, ${ }^{3}$ NAS recommended that plutonium disposition strategies endeavor to attain the "Spent Fuel Standard" (SFS) objectives, defined as follows:

We believe that options for the long-term disposition of weapons plutonium should seek to meet a "spent fuel standard"-that is, to make this plutonium roughly as inaccessible for weapons use as the much larger and growing quantity of plutonium that exists in spent fuel from commercial reactors. ${ }^{3}$

DOE has subsequently revised the SFS definition:

The surplus weapons-usable plutonium should be made as inaccessible and unattractive for weapons use as the much larger and growing quantity of plutonium that exists in the spent nuclear fuel from commercial power reactors.

The enhanced SFS makes explicit the concept of material attractiveness, which was implicit in the NAS definition.

The SFS does not imply that conversion of the plutonium to spent nuclear fuel (SNF) is the only way to achieve the non-proliferation objectives, but rather that disposition approaches should effect an equivalent level of proliferation resistance. Thus, achieving SFS provides increased proliferation resistance by transforming surplus fissile materials into a less accessible form; it leads to decreased reliance on institutional barriers to protect the material from theft or diversion. 


\subsubsection{Decision Process Leading to ROD}

From its beginning, DOE/MD went forward with a decision process focused on providing an orderly and detailed analysis of potential alternatives for plutonium disposition as input to ROD. The detailed evaluations consist of a thorough assessment of the reasonable alternatives including technical, economic, nonproliferation, environmental impact, and other analyses. This evaluation process resulted in determination of preferred alternatives and support for ROD. $1,10-16$

The screening process, the first step in implementing the President's September 1993 Nonproliferation Policy, was completed in March 1995 with the publication of DOE's Summary Report of the Screening Process. ${ }^{10}$ That report summarized the results of a study conducted to identify a spectrum of reasonable alternatives for long-term storage and disposition of surplus weapons-usable materials (plutonium, HEU, and ${ }^{233} \mathrm{U}$ ). Thirty-five alternatives for plutonium disposition were considered in the screening analysis. Sixteen of these alternatives involved the use of uranium/plutonium MOX fuel in nuclear reactors to convert the plutonium to a form similar to that contained in commercial SNF.

Four of the reactor-based plutonium disposition alternatives, two borehole alternatives, and three immobilization alternatives were ultimately selected as reasonable plutonium disposition alternatives for further evaluation in PEIS and additional detailed technical, economic, and nonproliferation evaluations. The four reactor-based plutonium disposition alternatives chosen were existing light-water reactors (LWRs), [both pressurized-water reactors (PWRs) and boiling-water reactors (BWRs)]; the CANDU heavy-water reactors (HWRs); partially complete LWRs; and evolutionary LWRs].

Following the screening process, DOE/MD, using its national laboratories, initiated a more detailed analysis of the nine plutonium disposition alternatives that survived the screening process. Three "Alternative Teams" chartered by DOE and comprised of technical experts from across the DOE national laboratory complex conducted these analyses. One team was chartered for each of the major disposition classes (borehole, immobilization, and reactors). The FMDP Reactor Alternative Team (RxAT) conducted extensive analyses of the cost, schedule, technical maturity, S\&S, and other characteristics of reactor-based plutonium disposition. The results of the RxAT's analyses of the existing LWR, the CANDU, the partially complete LWR, and the evolutionary LWR alternatives are documented in a four-volume report, ${ }^{12-15}$ which was summarized in the FMDP Technical Summary Report, ${ }^{11}$ issued October 1996.

DOE issued a draft PEIS on March 8, 1996, and held a formal public comment period through June 7, 1996. After considering comments, DOE issued the final PEIS in December 1996. The final PEIS ${ }^{16}$ identifies the preferred alternative for long-term storage of weapons-usable fissile materials and the preferred alternative for disposition of surplus plutonium. The latter consists of pursuing a combination of immobilizing plutonium in glass or ceramic materials and irradiating MOX fuel in existing, domestic commercial reactors.

ROD was issued January 14, 1997, for the storage and disposition of weapons-usable fissile materials. The ROD summary section states:

DOE's strategy for disposition of surplus plutonium is to pursue an approach that allows immobilization of surplus plutonium in glass or ceramic material for disposal in a geologic repository pursuant to the Nuclear Waste Policy Act, and burning of some of the surplus plutonium as mixed-oxide (MOX) fuel in existing, domestic, commercial reactors, with subsequent disposal of the spent fuel in a geologic repository pursuant to the Nuclear Waste Policy Act. DOE may also burn MOX fuel in Canadian Deuterium Uranium [CANDU] reactors in the event of an appropriate agreement among Russia, Canada, and the United States, as discussed below. The timing and extent to which either or both of these disposition approaches (immobilization or MOX) are ultimately deployed will depend upon the results of future technology development and demonstrations, follow-on (tiered) site-specific environmental review, contract negotiations, and detailed cost reviews, as well as nonproliferation considerations, and agreements with Russia and other nations. DOE's program will be subject to the highest standards of safeguards and security throughout all aspects of storage, transportation, and processing, and will include appropriate International Atomic Energy Agency verification. 
Due to technology, complexity, timing, cost, and other factors that would be involved in purifying certain plutonium materials to make them suitable for potential use in MOX fuel, approximately 30 percent of the total quantity of plutonium (that has or may be declared surplus to defense needs) would require extensive purification to use in MOX fuel, and therefore will likely be immobilized. DOE will immobilize at least 8 metric tons (MT) of currently declared surplus plutonium materials that DOE has already determined are not suitable for use in MOX fuel. DOE reserves the option of using the immobilization approach for all of the surplus plutonium. 1

Much more information is given in ROD and other supporting documents.

\section{BACKGROUND AND SCOPE OF REACTOR-OPTION STUDIES}

During the 4-year period prior to issue of the final PEIS and ROD, several sets of reactor-based option studies were performed by reactor vendors regarding disposition of weapons-usable plutonium. These studies began in January 1993 when DOE initiated contracts with reactor vendors to explore three options-reactor-spiking, spent fuel, and destruction. Initial study reports were received in May 1993, and subsequent studies concentrated on the spent fuel option. These latter studies examined the use of new reactor designs and were completed in May 1994. ${ }^{17-19}$ Additional reactor studies were also carried out to further explore the use of existing LWRs and CANDU HWRs; these were received in mid-1994. ${ }^{20-23}$

The results of these early DOE-sponsored studies showed that the use of excess plutonium to produce MOX fuel for existing, evolutionary, or partially complete nuclear power plants was technically feasible and a promising path for plutonium disposition. This was confirmed by the NAS study, which concluded that the use of plutonium as fuel in existing nuclear power plants and vitrification of plutonium together with high-level radioactive waste were the most promising disposition options. ${ }^{3}$

After the screening review, ${ }^{10}$ four domestic, MOX-fueled reactor, plutonium disposition alternatives were chosen for further detailed technical, economic, and nonproliferation evaluations and were completed $^{12-15}$ in September and October of 1996. Additionally, studies were commissioned by DOE/MD for reactor vendors to examine optimization of the MOX fuel cycle and transitioning from LEU to MOX fuel cores. ${ }^{24-27}$

The January 1997 ROD $^{1}$ describes DOE's strategy for irradiating most of the surplus plutonium as MOX fuel in existing commercial reactors and immobilizing the remainder of the surplus plutonium in glass or ceramic material. The former alternative involves conversion of plutonium materials including pits, pure metal, and oxides into a pure oxide powder form, blending it with depleted uranium, and processing it into MOX fuel. The MOX fuel would be used in existing LWRs with a once-through fuel cycle (no reprocessing and subsequent reuse of the spent fuel). After the appropriate cooling period in the reactor plant spent fuel pool (approximately 10 years), the spent MOX fuel would be ready for dry storage or emplacement in a geological repository. If partially completed LWRs were completed by other parties, they would also be considered for the mission. In its ROD, DOE also stated that it would retain the option of using MOX fuel in CANDU reactors with the appropriate multilateral arrangements.

The following discussions provide some highlights concerning the reactor-based option studies. Only reactor options employing existing LWRs are being actively pursued at this time as stated in ROD; however, other reactor studies are included for completeness.

\subsection{PLUTONIUM DISPOSITION STUDIES FOR NEW REACTOR DESIGNS}

The initial studies for DOE in January 1993 evaluated three options for the disposition of up to 100 MT of weapons-usable plutonium in reactors: spent fuel, reactor-spiking, and maximum destruction. The spent fuel option refers to a once-through MOX fuel cycle to process the weapons-usable plutonium into spent fuel, which is similar to low-enriched uranium (LEU) spent fuel in both radioactivity and isotopic composition of the contained plutonium. The reactor-spiking option involves a significantly shorter irradiation period compared with the spent fuel option. The resulting (reactor-spiked) spent fuel is less 
radioactive, and the contained plutonium is less changed isotopically. The maximum destruction option employs fission and transmutation of the plutonium in a nuclear reactor so that very little plutonium remains. This latter option involves fuel reprocessing and plutonium recycle and represents a large increase in technical uncertainty, cost, and mission time compared with the other two options.

Three vendors participated in the early studies: Westinghouse Electric Corporation (Westinghouse), General Electric (GE) Nuclear Energy, and Asea Brown Boveri-Combustion Engineering, Inc. (ABB-CE); each promoted advanced reactor designs as one way of achieving the mission. Following the initial reports, the focus was conversion to the SFS 1,16 with disposition of 50 or $100 \mathrm{MT}$ of plutonium. Westinghouse proposed two reactor designs-a 600-MW(e) reactor called the PDR600, based on their commercial AP600 reactor design; and a 1400-MW(e) reactor called the PDR1400, based on the large Westinghouse commercial reactor design. ${ }^{17}$ GE proposed the use of their 1300-MW(e) Advanced Boiling Water Reactor (ABWR), which has been designed to utilize full core loading of MOX fuel. ${ }^{18}$ ABWR was licensed in Japan, and two units were under construction. ABB-CE proposed the use of their System 80+ reactor with MOX fuel. ${ }^{19}$ The System $80+$ reactor retains the MOX fuel features of the System 80 reactor, which was originally designed for use of MOX fuel. Each of the vendor proposals promised to meet the mission objectives.

\subsection{PLUTONIUM DISPOSITION STUDIES FOR EXISTING REACTORS}

In early 1994, the reactor vendor studies were redirected to explore the use of MOX fuels in existing commercial reactor plants. The ground rules included optimization of the amount of plutonium throughput, using up to a full core of MOX fuel elements. The use of integral neutron absorbers was allowed in the MOX fuel rods.

In addition to Westinghouse, $\mathrm{GE}$, and $\mathrm{ABB}-\mathrm{CE}, \mathrm{AECL}$ Technologies was contracted to evaluate disposing of surplus U.S. weapons-usable plutonium as MOX fuel in existing CANDU reactors. The goal of these studies was to identify practical and safe options for the consumption of $50 \mathrm{MT}$ to $100 \mathrm{MT}$ of plutonium within a 25 -year period from the award of a contract.

Each of the U.S. LWR vendors ${ }^{20-22}$ generally concluded that it would be feasible to disposition $50 \mathrm{MT}$ of plutonium within a 25-year time frame utilizing three LWRs. Each individual vendor established that there are enough operating LWRs of their own design that could be used to complete the mission within the remaining lifetime of the existing plants, and each vendor offered preliminary MOX fuel designs that would allow the mission to succeed. In the case of the CANDU reactors, use of the 825-MW(e) Bruce A generation station reactors would meet the mission goals. ${ }^{23}$

\subsection{REACTOR ALTERNATIVE SUMMARY REPORTS}

Four reactor-based plutonium disposition alternatives were selected along with certain borehole and immobilization options for further evaluation as a result of the DOE screening process. ${ }^{10}$ An objective of the next phase of evaluations was to allow more detailed comparisons among these reactor, borehole, and immobilization options. The plutonium disposition mission ground rules were altered from the earlier studies. Revised ground rules specified that disposition of 32.5 MT to 50 MT of plutonium should begin within $\sim 10$ years and be completed within 25 years of issuing ROD. The reactor fuel loading scheme should be optimized to obtain the maximum plutonium throughput. The use of integral neutron absorbers in the MOX fuel rods and the use of full-core MOX fuel elements was also considered to maximize throughput.

Detailed technical, economic, and nonproliferation evaluations of the four selected reactor-based plutonium disposition alternatives-existing LWRs, CANDU HWRs, partially complete LWRs, and evolutionary LWRs-were completed in support of PEIS and ROD. The resulting four-volume FMDP Reactor Alternative Summary Report ${ }^{12-15}$ was issued in September and October 1996. These reports are summarized in the Technical Summary Report for Surplus Weapons-Usable Plutonium Disposition, ${ }^{11}$ which was issued in October 1996. 


\subsubsection{Existing LWR Alternative}

The existing LWR alternative base case assumed that five LWRs were used to irradiate the MOX fuel to meet SFS. For this analysis, five existing commercial Westinghouse-design PWRs [3411 MW(t), $1150 \mathrm{MW}(\mathrm{e})]$ were employed as surrogates for all domestic LWRs. This selection was not made because of perceived technical superiority among competing reactors, but rather because of the similarity in size to the majority of large PWRs available for plutonium disposition. Existing GE BWRs and ABB-CE LWRs were also evaluated and found suitable to complete the mission (no analysis for ABB-CE LWRs was published in the Reactor Alternative Summary Report). The results are documented in Vol. 1 of the FMDP Reactor Alternative Summary Report. ${ }^{12}$

\subsubsection{CANDU HWR Alternative}

The CANDU alternative was retained as an option in PEIS. The base case evaluated was the Bruce Nuclear Generating Station near Kincardin, Ontario. Two CANDU HWRs would operate on a reference MOX CANDU fuel for 5 years followed by all four plants operating on an advanced fuel known as CANFLEX. The existing CANDU reactor alternative base case study is documented in Vol. 2 of the FMDP Reactor Alternative Summary Report. ${ }^{13}$

\subsubsection{Partially Complete LWR Alternative}

The partially complete LWR alternative assumed the use of two large partially complete commercial LWR plants that would be completed and licensed for full MOX cores. Two ABB-CE System 80 PWRs [3817 MW(t) and $1256 \mathrm{MW}(\mathrm{e})$ ], each operating at a capacity factor of $80 \%$, were chosen as surrogates for fuel throughput calculations. At present, the Tennessee Valley Authority's Bellefonte-1 and -2 units appear to be the only viable "partially complete" reactors that would allow both licensing of a single type of reactor and completion of the overall mission in the desired time frame. This case study is documented in Vol. 3 of the FMDP Reactor Alternative Summary Report. ${ }^{14}$

\subsubsection{Evolutionary LWR Alternative}

The evolutionary LWR alternative assumed the use of new LWR designs to irradiate the MOX fuel. The new LWR designs considered were the four reactor designs promoted by the reactor vendors in the 1993-1994 plutonium disposition studies: the ABB-CE System 80+, GE ABWR, Westinghouse PDR1400, and the Westinghouse PDR600. The surrogate representative reactors chosen for the evolutionary LWR alternative study were two ABB-CE System 80+ PWRs [3817 MW(t) and $1256 \mathrm{MW}(\mathrm{e})]$ operating at a capacity factor of $80 \%$ and utilizing MOX fuel containing an average of $6.8 \mathrm{wt} \%$ plutonium in heavy metal. The alternative study is documented in Vol. 4 of the FMDP Reactor Alternative Summary Report. ${ }^{15}$

\subsection{OPTIMIZATION AND IMPLEMENTATION STUDIES FOR EXISTING REACTORS}

In January 1996, DOE's Office of Fissile Material Disposition commissioned a study to address four specific issues concerning the implementation of plutonium disposition in existing operating plants. Task 1 of this study was to evaluate the technical issues associated with transitioning an operating reactor from a $\mathrm{UO}_{2}$ core to a MOX core (without the use of integral neutron absorbers in the MOX fuel) as well as optimization of the fuel cycle. The additional tasks were to examine the licensing of MOX fuel in operating plants, define specifications for the MOX fuel, and define the requirements for MOX fuel qualification.

The primary assumption for this study was the disposition of $50 \mathrm{MT}$ of surplus weapons-usable plutonium giving due consideration to safety, environmental protection, $S \& S$, economics, and nonproliferation concerns. The core designs proposed should permit the maximum plutonium throughput without impacting the existing safety envelope, with minimum plant modifications, and without requiring protracted fuel development programs.

The core designs were developed within ground rules established by DOE, which allowed implementation in existing reactors with no significant impact on the utility. Weapons-usable 
plutonium-based $\mathrm{MOX}$ designs should (1) match existing $\mathrm{UO}_{2}$ core designs as much as possible, (2) have no significant impact on plant operation, and (3) require no significant plant modifications. It was also directed that the fuel designs not include integral burnable neutron absorbers in the MOX fuel. DOE regards the likely research and development needs for MOX fuel with integral burnable absorbers as possibly conflicting with the desired disposition schedule.

The four vendors participating in the 1994 studies of existing reactors were again contracted for the 1996 studies-Westinghouse Electric, GE Nuclear Energy, ABB-CE, and AECL Technologies, Inc. These studies were completed and reports issued in September 1996. Some highlights concerning the core optimization studies are discussed in the following sections.

\subsubsection{Westinghouse Electric Corporation}

The 1996 Westinghouse report ${ }^{24}$ describes a viable approach to transitioning from a full $\mathrm{UO}_{2}$ core to either a partial MOX core or to a full MOX core. Equilibrium rates for plutonium disposition are estimated at $0.433 \mathrm{MT} / \mathrm{year}$ for the partial MOX core case and $1.13 \mathrm{MT} / \mathrm{year}$ for the full MOX core case. The assumed fuel design was Westinghouse Vantage-5 fuel, which is currently used in the Plant Vogtle reactors located near Augusta, Georgia. A capacity factor of $90 \%$ was assumed, typical for the Plant Vogtle reactors.

The approach required three fuel loading cycles to reach the partial core equilibrium state and four loading cycles to reach the full MOX core state. MOX disposition using the partial MOX fuel core did not require any changes to the reactor systems. Standard discrete burnable absorbers are used in the MOX fuel assemblies (no integral absorbers are used in the MOX fuel) for all cases presented. It is suggested that operation at the full MOX core condition can be done by changing to higher worth control rods and using $40 \%$ enriched (in ${ }^{10} \mathrm{~B}$ ) soluble boron in the reactor coolant system. These changes are not required for the partial MOX core.

\subsubsection{GE Nuclear Energy}

The 1996 GE report ${ }^{25}$ describes two new MOX fuel designs that almost double the plutonium disposition rates in analogous fuel designs reported in 1994. The two new designs were identified as $\mathrm{UO}_{2}$ "look-alike" MOX fuel designs, referred to as the $\mathrm{UO}_{2}$-alike design, and a higher plutonium throughput partial-MOX fuel referred to as the High-MOX design. GE also volunteered additional data from its commercial development activities for Full-MOX fuel designs in which gadolinium is used as an integral burnable absorber in some of the MOX fuel rods. Use of the relatively new GE-11 fuel bundle design (which has been licensed and in commercial operation since 1992) was assumed for all cases. The plutonium throughput capabilities of these three MOX fuel types, all with an 18-month fuel cycle reload core design, are $\mathrm{UO}_{2}$-alike- $0.43 \mathrm{MT} /$ reactor/year, High-MOX $-0.83 \mathrm{MT} /$ reactor/year, and Full-MOX$1.5 \mathrm{MT} / \mathrm{reactor} / \mathrm{year}$. An $80 \%$ capacity factor was assumed.

All of the MOX fuel designs examined use MOX fuel pellets in place of $\mathrm{UO}_{2}$ pellets in an existing licensed BWR fuel bundle. No fuel bundle mechanical changes would be required. No reactor plant systems, equipment changes, additions, or design basis changes would be required. The MOX core designs would operate within the limits for LEU core designs for normal, transient, accident, and abnormal event conditions.

\subsubsection{ABB-CE}

ABB-CE's 1996 report $^{26}$ evaluated four (very similar) possible equilibrium MOX core loads for existing System 80 reactors. The results of the core analyses estimated that throughputs of 0.91 to $0.98 \mathrm{MT}$ of weapons-usable plutonium per year per System 80 reactor could be achieved, assuming no integral burnable absorber in the MOX fuel. Analysis was also presented for an option using an integral burnable absorber, giving a throughput of 1.22 MT of weapons-usable plutonium per year per reactor for an equilibrium cycle based on $100 \%$ of the fuel rods containing MOX.

The three ABB-CE System 80 PWRs in operation at the Palo Verde Nuclear Generating Station were specifically designed (in the 1970s) to accommodate a full core loading of MOX fuel. As a result, these 
units have capacity for the additional control rod worth, the higher decay heat loads, and for higher boron distribution levels in the main coolant system and safety cooling systems that would be desired for a HighMOX loading. No plant modifications and no significant impact on operations were reported for the cases examined.

\subsubsection{AECL Technologies, Inc., Study of CANDU Reactors}

The 1996 core optimization study ${ }^{27}$ for use of weapons-usable plutonium MOX fuel in CANDU reactors was conducted by AECL Technologies, the U.S. Office of Atomic Energy of Canada. Ontario Hydro's four $825-\mathrm{MW}(\mathrm{e})$ Bruce A generating station reactors were the reference for this study (and the 1994 study). Enhanced fuel designs were developed to permit an annual throughput of up to $2.9 \mathrm{MT}$ of plutonium using two Bruce A reactors and up to 4.8 MT using four Bruce A reactors and an advanced fuel bundle design referred to as CANFLEX fuel.

\section{REFERENCES}

1. Record of Decision for the Storage and Disposition of Weapons-Usable Fissile Materials Final Programmatic Environmental Impact Statement, U.S. Department of Energy, Office of Fissile Materials Disposition, January 14, 1997.

2. Program Acquisition Strategy for Obtaining Mixed-Oxide Fuel Fabrication and Reactor Irradiation Services, U.S. Department of Energy, Office of Fissile Materials Disposition, May 1997.

3. National Academy of Sciences, Management and Disposition of Excess Weapons Plutonium, National Academy Press, 1994.

4. Presidential Decision Directive-13, U.S. Nonproliferation and Export Control Policy, September 27, 1993.

5. Storage and Disposition of Weapons-Usable Fissile Materials Final Programmatic Environmental Impact Statement, Vol. III, "Appendix A," DOE/EIS-0229, U.S. Department of Energy, Office of Fissile Materials Disposition, December 1996.

6. President Clinton's Address to The Nixon for Peace and Freedom Policy Conference, March 1, 1995.

7. U.S. Department of Energy Openness Initiative, February 6, 1996.

8. National Academy of Sciences, Management and Disposition of Excess Weapons Plutonium, Reactor-Related Options, National Academy Press, 1995.

9. Joint Declaration from Moscow Nuclear Safety Summit, April 20, 1996.

10. Summary Report of the Screening Process, DOE MD-0002, U.S. Department of Energy, Office of Fissile Materials Disposition, March 29, 1995.

11. Technical Summary Report for Surplus Weapons-Usable Plutonium Disposition, DOE/MD-0003, Rev. 1, U.S. Department of Energy, Office of Fissile Materials Disposition, October 1996.

12. Reactor Alternative Team, Fissile Materials Disposition Program, FMDP Reactor Alternative Summary Report, Vol. 1-Existing LWR Alternative, ORNL/TM-13275/V1, Lockheed Martin Energy Research Corp., Oak Ridge National Laboratory, October 7, 1996.

13. Reactor Alternative Team, Fissile Materials Disposition Program, FMDP Reactor Alternative Summary Report, Vol. 2-CANDU Heavy Water Reactor Alternative, ORNL/TM-13275/V2, Lockheed Martin Energy Research Corp., Oak Ridge National Laboratory, September 1996.

14. Reactor Alternative Team, Fissile Materials Disposition Program, FMDP Reactor Alternative Summary Report, Vol. 3-Partially Complete LWR Alternative, ORNL/TM-13275/V3, Lockheed Martin Energy Research Corp., Oak Ridge National Laboratory, September, 1996.

15. Reactor Alternative Team, Fissile Materials Disposition Program, FMDP Reactor Alternative Summary Report, Vol. 4-Evolutionary LWR Alternative, ORNL/TM-13275/V4, Lockheed Martin Energy Research Corp., Oak Ridge National Laboratory, September 1996. 
16. Storage and Disposition of Weapons-Usable Fissile Materials Final Programmatic Environmental Impact Statement, "Summary" and Vols. I, II, III, and IV, DOE/EIS-0229, U.S. Department of Energy, Office of Fissile Materials Disposition, December 1996.

17. Westinghouse Electric Corporation, PDR Plutonium Disposition Study Phase II Final Report, Vols. I and II, DOE/SF/19683-5, U.S. Department of Energy, April 30, 1994 (Predecisional-Not for Public Release).

18. Study of Plutonium Disposition Using the GE Advanced Boiling Water Reactor (ABWR), NEDO32351, GE Nuclear Energy, April 30, 1994 (Predecisional-Not for Public Release).

19. DOE Plutonium Disposition Study-Screening Study for Evaluation of the Potential for System 80+

to Consume Excess Plutonium, ABB-Combustion Engineering, Inc., April 30, 1994 (Predecisional-Not for Public Release).

20. Plutonium Disposition in Existing Pressurized Water Reactors, DOE/SF/19683-6, Westinghouse Electric Corporation, June 1, 1994 (Predecisional--Not for Public Release).

21. Study of Plutonium Disposition Using Existing GE Boiling Water Reactors, NEDO-32361, GE Nuclear Energy, June 1, 1994 (Predecisional-Not for Public Release).

22. DOE Plutonium Disposition Study, Analysis of Existing ABB-CE Light Water Reactors for the Disposition of Weapons-Grade Plutonium, ABB-Combustion Engineering, Inc., June 1, 1994 (Predecisional-Not for Public Release).

23. Plutonium Consumption Program CANDU Reactor Project, AECL Technologies, Inc., July 31, 1994 (Predecisional-Not for Public Release).

24. Westinghouse Electric Corporation, Plutonium Disposition Study, Implementation of Weapons Grade MOX Fuel in Existing Pressurized Water Reactors, DOE/SF/19683-7, U.S. Department of Energy, August 30, 1996 (Predecisional-Not for Public Release).

25. Optimization and Implementation Study of Plutonium Disposition Using Existing GE Boiling Water Reactors, NEDO-32638, GE Nuclear Energy, September 30, 1996 (Predecisional-Not for Public Release).

26. DOE-Plutonium Disposition Study, Core Designs for Existing ABB-CE System 80 Reactors for the Disposition of Weapons-Grade Plutonium, ABB-Combustion Engineering, October 25, 1996 (Predecisional-Not for Public Release).

27. Optimization and Implementation Study of Plutonium Disposition Using Existing CANDU Reactors, AECL Technologies Inc., September, 1996 (Predecisional-Not for Public Release). 
APPENDIX A:

\section{HOW TO OBTAIN SELECTED DOCUMENTS AND INFORMATION}

This section identifies and describes how to obtain a number of relevant documents that concern the Department of Energy's (DOE's) program for disposition of surplus plutonium. Note that some of the nuclear reactor vendor reports cited are predecisional, and some contain proprietary information and have not been approved for public release.

\section{A.1 DOCUMENTS AVAILABLE FROM DOE'S OFFICE OF FISSILE MATERIALS DISPOSITION (MD)}

A number of documents can be obtained by contacting DOE/MD at the address below. Some may also be obtained from the DOE/MD World Wide Web (WWW) page at http://web.fie.com/htdoc/fed/doe/fsl/ $\mathrm{pub} / \mathrm{menu} / \mathrm{any}$, although in some cases documents are only available in partial form.

\section{U.S. Department of Energy}

Office of Fissile Materials Disposition, MD-4

Forrestal Building

1000 Independence Avenue, SW

Washington, D.C. 20585

Phone: (202) 586-5413

- Record of Decision for the Storage and Disposition of Weapons-Usable Fissile Materials Final Programmatic Environmental Impact Statement, U.S. Department of Energy, Office of Fissile Materials Disposition, January 14, 1997.

- Available on the WWW at http://web.fie.com/htdoc/fed/doe/fsl/pub/text/any/doedn020.htm

- Storage and Disposition of Weapons-Usable Fissile Materials Final Programmatic Environmental Impact Statement Summary, DOE/EIS-0229, U.S. Department of Energy, Office of Fissile Materials Disposition, December 1996.

- Available on the WWW at http://web.fie.com/htdoc/fed/doe/fsl/pub/text/any/doedn018.htm

- Available to the public from the National Technical Information Service, 5285 Port Royal Road, Springfield, VA 22161.

- Storage and Disposition of Weapons-Usable Fissile Materials Final Programmatic Environmental Impact Statement, Volumes I, II, III, and IV, DOE/EIS-0229, U.S. Department of Energy, Office of Fissile Materials Disposition, December 1996.

- Available to the public from the National Technical Information Service, 5285 Port Royal Road, Springfield, VA 22161.

- Technical Summary Report for Surplus Weapons-Usable Plutonium Disposition, Rev. 1, DOE/MD0003, U.S. Department of Energy, Office of Fissile Materials Disposition, October 1996.

- Available on the WWW at http://web.fie.com/htdoc/fed/doe/fsl/pub/text/any/doedn013.htm

- Joint United States/Russian Plutonium Disposition Study, September 1996.

- The Executive Summary is available on the WWW at http://web.fie.com/htdoc/fed/doe/fsl/pub/text/ any/doedn016.htm

- Summary Report of the Screening Process, DOE MD-0002, U.S. Department of Energy, Office of Fissile Materials Disposition, March 29, 1995.

- Available on the WWW at http://web.fie.com/htdoc/fed/doe/fsl/pub/text/any/rep21.htm (Due to limitations of the webpage system, figures and graphics are discussed rather than displayed for the version available on the WWW.) 


\section{A.2 FMDP REACTOR ALTERNATIVE SUMMARY REPORTS}

The following reports are available to the public from the National Technical Information Service, U.S. Department of Commerce, 5285 Port Royal Road, Springfield, VA 22161. These reports are available to DOE and DOE contractors from the Office of Scientific and Technical Information, P.O. Box 62, Oak Ridge, TN 37831, telephone (423) 576-8401.

- FMDP Reactor Alternative Summary Report, Vol. 1-Existing LWR Alternative, ORNL/TM-13275/V1, Lockheed Martin Energy Research Corp., Oak Ridge National Laboratory, October 7, 1996.

- FMDP Reactor Alternative Summary Report, Vol. 2-CANDU Heavy Water Reactor Alternative, ORNL/TM-13275/V2, Lockheed Martin Energy Research Corp., Oak Ridge National Laboratory, September 1996.

- FMDP Reactor Alternative Summary Report, Vol. 3-Partially Complete LWR Alternative, ORNL/ TM-13275/V3, Lockheed Martin Energy Research Corp., Oak Ridge National Laboratory, September 1996.

- FMDP Reactor Alternative Summary Report, Vol. 4-Evolutionary LWR Alternative, ORNL/ TM-13275/V4, Lockheed Martin Energy Research Corp., Oak Ridge National Laboratory, September 1996.

\section{A.3 DOCUMENTS AVAILABLE FROM NATIONAL ACADEMY PRESS}

The following NAS reports are available from National Academy Press, 2101 Constitution Avenue, N.W., Box 285, Washington, D.C. 20055, telephone (800) 624-6242 or (202) 334-3313.

- Management and Disposition of Excess Weapons Plutonium, National Academy of Sciences, National Academy Press, 1994 (the "Executive Summary" and much of the "Recommendations" section are available on the WWW at http://web.fie.com/htdoc/fed/doe/fsl/pub/text/any/pub3a.htm).

- Management and Disposition of Excess Weapons Plutonium, Reactor-Related Options, National Academy of Sciences, National Academy Press, 1995. 
ORNL/TM-13416

Dist. Category UC-523

\section{INTERNAL DISTRIBUTION}

1. S. L. Byerly

2. E. C. Fox

3. S. R. Greene

4. G. T. Mays

5. G. E. Michaels

6. D. G. O'Connor

7. P. L. Rittenhouse

8. B. B. Bevard
9. C. C. Southmayd

10. D. J. Spellman

11. J. F. Thomas

12. D. L. Williams

13. Central Research Library

14-15. ORNL Laboratory Records (OSTI)

16. ORNL Laboratory Records-RC

\section{EXTERNAL DISTRIBUTION}

17. D. J. Nulton, U.S. Department of Energy, MD-4, Forrestal Building, Room 6G-050, 1000 Independence Avenue SW, Washington, DC 20585.

18-22. P. T. Rhoads, U.S. Department of Energy, MD-3, Forrestal Building, Room 6G-050, 1000 Independence Avenue SW, Washington, DC 20585.

23. J. J. Buksa, Los Alamos National Laboratory, P.O. Box 1663, MS-F628, Los Alamos, NM 87545.

24. T. Barr, U.S. Department of Energy, EPG, Argonne National Laboratory, 9800 South Cass Avenue, Argonne, IL 60439.

\section{WWW DISTRIBUTION}

The FMDP Web site, with a list of other relevant topical reports, is located at the following URL:

http://www.ornl.gov/etd/FMDP/fmdpproc.htm 